\title{
Diplomacy Narratives as Documents of Performance
}

\author{
Mark Hutchings
}

The proposition that early modern diplomacy was theatrical is hardly a controversial one, yet in the main the analogy tends to be deployed rhetorically, giving the impression that 'theatricality' requires no further elucidation.* Moreover, the texts on which our understanding of the significance of protocol and ceremonial is based are rarely interrogated for their performative or quasiperformative characteristics - or, as I shall argue in what follows, approached in terms of their original function. This chapter explores a deceptively simple hypothesis: if ceremonial was central to the practice of diplomacy, as William Roosen urged forty years ago, what might it mean to treat accounts of diplomatic activity as documents of performance? ${ }^{1}$

Like drama, diplomacy depended on actors and audiences; and like drama it was scripted, choreographed, and (sometimes) presented in print to serve as a putative record of the event - which, in turn, invited an imaginative reenactment on the part of the reader. Indeed, sometimes the two overlap seamlessly, such as we find in textual accounts of performance events in the dispatches to Philip II I from Spain's ambassador to the court of James I and VI in 1604, during the peace-making that led up to the signing of the Treaty of London. In such cases key features of diplomacy, or rather the rendering thereof through writing, are hardly distinguishable from theatrical texts (here a court masque and a royal entry into the capital). ${ }^{2}$ The ordering and procession of persons recorded, that is, serve overlapping and intersecting purposes of diplomatic

* An earlier version of this essay was delivered at the 3 rd International Conference on Anglo-Iberian Relations: From the Medieval to the Modern held at the University of Oviedo, 14-16 November 2019. I would like to thank the Organizing Committee for the opportunity to try out some of the ideas reproduced here on that occasion.

1 Roosen W., "Early Modern Diplomatic Ceremonial: A Systems Approach", Journal of Modern History $5^{2,} 3$ (1980) $45^{2-476 .}$

2 See Cano-Echevarría B. - Hutchings M., "The Spanish Ambassador and Samuel Daniel's Vision of the Twelve Goddesses: A New Document [with Text]", English Literary History 42, 3 (2012) 223-257, and Hutchings M. - Cano Echevarría B., "The Spanish Ambassador's Account of James I's Entry into London, 1604 [with Text]", The Seventeenth Century 33, 3 (2018) 255-277. 
account and theatrical choreography. Our knowledge of one such episode, the visit of an English embassy to Valladolid in 1605 to ratify the Treaty of London, is largely dependent on surviving first-hand (notionally eyewitness) accounts, in Spanish, Portuguese, and English, and it is the last of these I am going to focus on in this chapter.

One way to tell this story is to bring together the surviving English, Spanish, and Portuguese witnesses to establish, as best as one can, what took place. But that of course was not the intention of the writers of these texts, whose audience was domestic and partial, rather than putatively international; although texts did circulate, few if any people - even monarchs - were in a position to carry out the kind of comparative analysis scholars practice today, even had it been considered desirable to do so. ${ }^{3}$ There is good reason, therefore, to approach these texts as discrete entities, and to resist the historicizing imperative of modern scholarship. It is understandable that, for historians, surviving texts, scrupulously mined for information, provide the evidentiary basis of modern narrative reconstructions (in as much as they can be) of past events. Thus sifted, however, these early modern texts rarely speak as themselves - in other words, except perhaps (and then only to a degree) for specialists who return to the original documents, these texts no longer function as they were so designed, since they only appear partially, fragmented, in selective quotation. Notwithstanding the unavoidable convention of quotation and omission, this essay explores how they might do so, and on what terms: how, in returning the wheat to the discarded chaff, such narratives may speak afresh. For originally, they did so in ways that illuminates our understanding of both diplomacy and its dissemination in the period. What this 'formalist' approach lacks in contextual thoroughness it gains in the kind of close reading that, I will argue, both reveals the purpose for which these texts were designed and hints at the ways in which they were read.

There are certainly sound hermeneutic as well as aesthetic reasons for filleting out the apparently less interesting material: this genre is by no means rewarding, in conventional terms, at least at first, and rarely repays the kind of critical endeavour informed by literary approaches or sensibilities. But then these texts were not designed to serve such purposes, their function being to provide reliable, factual (that is, quasi-objective) information within a circumscribed environment, rather than capture the subjective views or opinions of their authors; indeed, far from offering reader or writer an opportunity to

3 James I did acquire a copy of the Spanish Relacion documenting the embassy's visit to London, published in Seville 1604, but this kind of collecting ought not to be taken for or confused with a more modern notion of scholarship. 
range imaginatively beyond the ostensible subject matter, these texts are characterized by a deliberate simplicity of expression in the service of (apparent) objectivity on the one hand and precision of narrative focus on the other. In other words, they are rather dull. Mary C. Fuller has written about the 'dullness' of much of the material Richard Hakluyt assembled in his monumental Principal Navigations (1589; 1598-1600), pointing out how historians and literary scholars tend to approach the collection quite differently, the latter rarely finding the texts aesthetically rewarding. ${ }^{4} \mathrm{~A}$ similar challenge awaits the modern reader of diplomacy narratives, such as the account I am going to focus on in this chapter. Robert Treswell concludes his address 'To the Reader' that prefaces A Relation of Svch Things As were obserued to happen in the Journey of the right Honourable Charles Earle of Nottingham, L. High Admirall of England, his hignesse Ambassadour to the King of Spaine, with a concession that, on the surface, appears to be no more than a sop to the conventions of such paratexts. 'In reporting whereof', he writes, 'I had rather be condemned for plainnesse, than once suspected for reporting an untrueth. ${ }^{6}$ The reader is certainly in for a lot of 'plainnesse'. This is not, however, to be taken as an apology (or mock apology) for a deficiency in skill or style; quite the contrary. For records of diplomatic missions were in part intended as prose 're-performances' of the events they represented; while they functioned as a form of propaganda (rather than travelogue, say, or mere generalized news report), their conventions were specific to both diplomacy and its dissemination. For 'plainnesse' read accuracy and design, precisely to avoid 'untrueths'; this unornamental style, moreover, does not lack detail, but serves as a coding system, not only in terms of both record and reception but also design. Treswell was a herald, an office whose duties included the choreographing of ceremonial for the event that was to take place. His account of the Earl of Nottingham's embassy to Spain in 1605 conforms to the requirements of that office (and the conventions of the genre), and in so doing was designed to convey to the reader what was important: 'plainnesse' of fact, unadorned by ornament that might obscure or divert the reader's understanding of the import of what was being communicated.

4 See Fuller M.C., "His dark materials': The Problem of Dullness in Hakluyt's Collections", in Carey D. - Jowitt C. (eds.), Richard Hakluyt and Travel Writing in Early Modern Europe (London - New York: 2016) 231-242. Hakluyt's original collection was expanded into three volumes and published at the end of the sixteenth century.

5 On the significance of such materials see for example Smith H. - Wilson L. (eds.), Renaissance Paratexts (Cambridge: 2011).

6 Treswell Robert, A Relation of Svch Things As were obserued to happen in the Journey of the right Honourable Charles Earle of Nottingham, L. High Admirall of England, his hignesse Ambassadour to the King of Spaine (London, Melchisedech Bradwood: 1605) Biv. 
Indeed, Treswell had a further reason to stress this virtue because he was aware of what he describes as 'a Pamphlet of many false and erroneous obseruations' recently published, which his version purports to correct. That text, penned by an anonymous member of the mission who styles himself as 'a better souldier then a Scholler', is similarly framed: 'I abhorre not the English I was borne to, neither will I go about to plucke from the Inkhorne any solemne Paraphrases, to set forth that, which rather (for the truth therof) desires a plaine and easie deliuerie. ${ }^{7}$ Here, then, we are a very long way from the discussion and appreciation of 'ornament' in George Puttenham's The Art of English Poesy, for example. ${ }^{8}$ The nature of such texts, and the conventions underpinning them, requires the scholar to privilege 'plainnesse' (and what it meant to the early modern reader) over literariness, which we naturally value today and whose absence we tend to lament. To read and understand these texts now requires a recalibration of value.

If the rendering of diplomatic ceremonial textually, for dissemination, was not ornamental in substance, nor was the practice itself, as Roosen demonstrated. Writing in 1980, he observed that scholars have been slow or reluctant to appreciate the significance of protocol and ceremonial, tending to regard them as 'a hindrance to rather than a necessary and essential part of effective diplomacy'. In other words, the modern perception that ceremonial was and is but the precursor to the serious business that follows, behind-the-scenes, has obscured our understanding of these early modern practices. If that is no longer the case now, nonetheless Diplomacy Studies lacks a theoretical underpinning of its treatment of ceremonial. One question that might be put, then, is how we might conceptualise the performative nature of diplomacy; and one answer, I propose, is to focus on the texts as records of performance, drawing on another comparatively recent development in the academy, Performance Studies. ${ }^{10}$

Once we think of the offices of diplomat or herald in terms of theatremaking it becomes possible to forge a more direct link between the practice of diplomacy, the staging of performance, its dissemination as text, and reception

7 The Royal Entertainment of the Right Honourable the Earle of Nottingham, sent Ambassador from his Maiestie to the King of Spaine (London, Valentine Sims: 1605) A3r.

8 See Wigham F. - Rebhorn W.A. (eds.), The Art of English Poesy by George Puttenham: A Critical Edition (Ithaca and London: 2007); especially relevant is Book 3, 'Of Ornament', 221-387.

9 Roosen, "Early Modern Diplomatic Ceremonial" 453.

10 For a discussion of how early modern historians conceptualized space in their rendering of ceremonial, see for example Dillon J., "The Trials of Queen Katherine in Henry VIII", Shakespeare Survey 63 (2010) 149-161. 
by domestic audiences. Heralds like Treswell were responsible for scripting events according to the rules of protocol, so that ceremonial was choreographed precisely, respecting matters of rank and hierarchy through the laws of proxemics and procession; in the case of A Relation of Svch Things, Treswell is not only the figure behind this scripting of diplomacy but also responsible for narrating these events into prose. For this reason, the text has a particular authority. The event is choreographed, experienced (for the most part), and written up by him, the principal agent in both the performance of the embassy and its textual re-presentation. Although not involved in the organizing of either the Hampton Court masque or royal entry into London, both of which he witnesses first-hand, the Spanish ambassador takes similar care in the presentation of the texts he has drawn up and sent to his master, Philip III. It is telling that the Conde de Villamediana's texts are rendered according to the conventions of their respective genres. Both texts (masque and royal entry) preserve - and indeed insist upon the reader grasping - a sense of the event as an unfolding narrative performance, framed with a beginning and an ending: these are texts that operate on the page, that is, to give the impression of rolling chronological time. This attention to sequence, and its preclusion of any kind of retrospective knowledge - presenting the reader with a temporallybound performance experience - is a signal characteristic of diplomatic writing dealing with official events. In literary terms, using the Russian Formalists' distinction between fabula and sjuzet, where fabula represents the actual chronology of events represented and sjuzet the arrangement (plotting) of these events in a narrative sequence that may but usually (in literary fictions) does not coincide with the fabula, ambassadors' and heralds' accounts conform to the fabula model. Although not entirely free of interpretative intervention (no writing can be), the writers of these texts strive not only for accuracy but also to convey the event as a narrative that precisely parallels (and indeed $i s$, in the act of reading) the action - not unlike, by anachronistic analogy, early cinema before technological advances facilitated editing. Significantly, then, this genre invests in the reader interpretative agency, the conceit of this textual reperformance being that it offered a vicarious experience of the original event.

Before moving on to explore Treswell's text it may be worth thinking about how a printed play-text shapes its readers' interpretative experience, and use this as the basis for analysis of the account the herald provides of the English mission to Spain. The architecture of the printed play guides the reader, inviting her to engage in specific ways: stage directions are usually placed distinctly, in the margin or centred - in both cases set apart from the main text, their difference underscored usually by being printed in italic (a convention followed today); thus may we distinguish readily between the Haupttext, or main text, 
i.e. the dialogue, and Nebentext, the apparatus of stage directions, or side text." This division has periodically led to scholars making a distinction between authorial material - dialogue - and the theatrical provenance of stage directions, but recent studies attending to the status of these plays as experiences designed for readers have sought to connect (or reconnect) these two features. In questioning the traditional separation of dialogue from non-dialogue Douglas Bruster and Emma Smith open up fascinating ways of reading plays. ${ }^{12}$ Diplomacy narratives might be similarly approached, even if the premise is inverted: here I want to treat prose accounts as containing - and blending the Haupttext and Nebentext, understood as consisting of a different kind of distinction. In place of a dialogue/stage directions binary these prose texts consist primarily of scenarios framed and produced by entrances and exits, the choreography of the stagecraft precisely recorded - striking (in terms of the comparison being advanced, admittedly) for the absence of Haupttext dialogue. These texts, I propose, invite a specific kind of reading, whereby the Haupttext - conventionally understood, in terms of hierarchy, as the primary component - gives way to, or is subsumed by, indeed incorporated into, the Nebentext; and the Nebentext, here, correspondingly is key to how these accounts present early modern diplomatic ceremonial.

Thus it is that Treswell adopts a sparse, minimally descriptive approach that nonetheless records - indeed privileges - the visual elements of diplomacy, such as the placing and (most importantly) proximity of persons to one another, the clothing worn, and the spaces in which these events take place: in other words (to recall a device in playmaking), the text is a 'dumb show', since the Haupttext (dialogue) is (understandably) 'missing' from these accounts. In a recent discussion of this device Jeremy Lopez proposes that the dumbshow is 'a threshold between drama (a play as textual artefact) and theatricality (the quality of experience a play provides live and in real time).'.13 This sense of the visual-but-silent sequence of the dumb show as straddling print and performance is suggestive for the argument being advanced here, for the diplomacy narrative must also contest with the 'problem' of translating visual material into prose. But whereas Lopez finds dumbshow stage directions 'difficult to

\footnotetext{
11 The terms are Roman Ingarden's, developed in Das Literarische Kunstwerk (Halle: 1931). Margaret Jane Kidnie discusses the application of these terms in "Text, Performance, and the Editors: Staging Shakespeare's Drama", Shakespeare Quarterly 51, 4 (2000) 456-473.

12 See Smith E., "Reading Shakespeare's Stage Directions", and Douglas Bruster, "Shakespeare's Literary Stage Directions", in Dustagheer S. - Woods G. (eds.), Stage Directions and Shakespearean Theatre (London: 2018) 93-114, and 115-137 respectively.

13 Lopez J., "Dumb Show", in Turner H.S. (ed.), Early Modern Theatricality (Oxford: 2013) 291-305; here 292 (italics original).
} 
read', and argues that the in-between-ness of the device renders it unsatisfactory for either medium, in diplomacy narratives what I consider the equivalent of the dumbshow would appear to operate satisfactorily - based as it is on an ethos of 'plainnesse. ${ }^{14}$ Crucially the Nebentext does not compete with the Haupttext but displaces it altogether, so that that there is no perceived or actual conflict. Stripped of (unattainable) Haupttext, A Relation of Svch Things is an elaborate, extended form of Nebentext. Thus the 'side text' takes centre stage. In what follows I propose to read Treswell's account as essentially an elaborate, extended sequence of stage directions; in other words, as a record of performance, which, after Roosen, is key to early modern diplomacy, both in terms of diplomatic practice and its popular dissemination.

Treswell's account takes the reader from London, where the embassy is assembled and takes its leave of King James I \& VI, to Spain, where after a long journey to the court of King Philip III it is entertained in Valladolid, and then back to England. Instead of anchoring at Santander, as Philip anticipated, and travelling directly south to Valladolid from there the flotilla continues west to A Coruña, which necessitates a delayed and arduous journey through mountains south to the royal city. Once the embassy reaches Valladolid it becomes clear that Philip III has taken great care to choreograph the entire visit, with the city a theatre for the staging of the ratification of the peace; the birth of the future Philip IV in April enables his father to incorporate the baptismal procession and ceremony into the entertainments for the Earl of Nottingham, the preparations for which are aided by the embassy's late arrival following its landing at A Coruña. The Spanish king instructs Nottingham to remain there until sufficient supplies of horses and mules can be sent to transport the English south. In the meantime, the embassy is entertained by the governor of the town, and on its journey south this hospitality is repeated as the mission passes through a succession of small towns.

Treswell's role as herald and design as author of this account is particularly conspicuous in the text's presentation of the small-scale, set-piece entertainments Nottingham receives, first at A Coruña and then during the journey south. As noted earlier, this herald is both choreographer and recorder. The significance of this is that he is actually or vicariously present as narrator: his office, his status, gives him access. Thus, his text takes the reader into the elite, high-status world from which the vast majority would otherwise be excluded. This can be illustrated by a brief comparison with the 'rival' account, The Royal Entertainment, whose author Treswell describes (not unfairly) as 'not well

$14 \quad$ Ibidem 293. 
informed. ${ }^{15}$ Both texts implicitly proclaim, or betray, the extent, or limit, of their access to the events they recount - which reveals the witness's place in the social hierarchy; that is to say, that on occasion in the anonymous, 'pirate' text the author simply does not have access to the event, which as a consequence is either treated cursorily or omitted altogether. For example, whereas Treswell devotes two pages to the Lord Admiral's celebration of Saint George's Feast in A Coruña, the compiler of the other text, evidently neither present nor well informed, reports simply: 'the two and twentie Day of Aprill being Tuesday, his Lordship did keepe George his feast in the Gouverours house, in as great state as the place and time could afford, and his owne charges.' ${ }^{16}$ That Treswell is present on this occasion - as he would be, given his official duties is confirmed in the third person in the narrative: 'At the comming in of the second course, according to the fashion of England, the Kings stile was proclaimed in three seuerall languages by Somersett herauld cying, Largesse, who had a liberall reward for the same..17

A Relation of Svch Things is a succession of 'scenes', a number of them, such as the celebration of Saint George's Day here, intimate, private events. As Janette Dillon points out, in the European court kinesics (the movement of people) and proxemics (their relative spatial positioning) are crucial to how this world saw itself and was seen. ${ }^{18}$ While the text is a narrative account, a strictly chronological account, of the English embassy, Treswell (unsurprisingly, given the duties of his office) has an eye to the theatricality of the events he choreographs, often witnesses, and describes. He is alert to the importance of kinesics and proxemics, which constitute diplomatic protocol. He notes, for example, but need not comment on a detail that would be obvious to the early modern reader, how the Earl of Nottingham is greeted when the embassy arrives at a town on the route to Valladolid:

Sunday the fifth day of May we rode forward to a very faire towne called Lugo, being distant from Villa Alua seuen leagues. The Alcaylde [mayor] and other officers of the town, meeting his Lordship about halfe a mile without the gates, and accompanying vs into the towne, the streets being decked with bowes and the wals of their houses garnished with their best hangings and furniture. ${ }^{19}$

15 'To the Reader' A4r.

16 The Royal Entertainment, 2. For comparison see Treswell, A Relation of Svch Things 18-19.

17 Treswell, A Relation of Svch Things 19.

18 Dillon J., The Language of Space in Court Performance, 1400-1625 (Cambridge: 2010) 2.

19 Treswell, A Relation of Svch Things 25. 
The key detail concerns kinesics, the movement through space: the mayor shows his deference to the higher-ranked visitor by greeting Nottingham outside the town and escorting the entourage through the gates. It is a seemingly small yet key detail, rendered unobtrusively, even 'naturalistically': for Treswell and his readers the mayor is performing an act of respect to the King of England by proxy.

Even when not involved in the arrangements, as is plainly the case with entertainments laid on by the Spanish, Treswell is concerned to provide a description that conjures up a three-dimensional image for the reader, in this case an arena in Valladolid that will shortly host an elaborate masque:

Thursday the second day of May, there was prepared in the market place, a certaine peece of ground railed in square the space of twenty yeards or more, with Scaffolds, built of purpose about the same: wherein the English were very sufficiently appointed and placed, for the seeing of these sports. His Lordship and other the Noblement were placed in seuerall windows, in a very faire roome in the Kings Statehouse, being for that purpose hanged with rich Arras and seuerall clothes of estate ouer the windows, on the wall on the outside the house. ${ }^{20}$

Here we have the setting (and language) of theatrical performance. Treswell provides his reader with an idea of the size of the performance space, its shape, the demarcation of the playing arena (it is 'railed'), and the seating ('Scaffolds'). The placement of the Lord Admiral, and where, is a significant detail, of course, and it also lends a kind of hierarchical verticality to the evocation of the scene. Both the description of the theatre space and the implied point of view of Nottingham, from on high, helps the reader visualize the performance that follows in Treswell's text.

On two occasions Treswell takes a different approach. Just as Villamediana sets out the masque and royal entry in such a way as to best convey the movement of high-status figures through space and time, at points Treswell chooses to match the mis-en-page to the events being described. Two prominent examples, both consisting of lists of dignitaries, are the names of the senior members of the embassy and the identities of the Spanish caballeros who participate in the Juego de Cañas tournament in the plaza mayor in Valladolid. In the first of these, Treswell's list, which begins with 'The Earle of Pearth' and includes thirty-three names, ordered according to rank, each member is given his own

$20 \quad$ Ibidem 21. 
line on the page. ${ }^{21}$ It is a list but also, figuratively - visually - a procession, as if the members of the embassy are marching onto the ships that are also named, following a paragraph of prose giving other members of the mission below the rank of knight and concluding with the brief remark - accounting for some five hundred men - 'diuers whose names are not heerein remembered'. ${ }^{22} \mathrm{On}$ the following page this procession of names - a dramatis personae, as it were present themselves to the Lord Admiral:

the greatest number of them being very richly apparelled themselves and extraordinarily appointed for their seruants, gaue their attendance at Nottingham house the said one and twentie day of March, his Lordship hauing appointed many barges and boates for conueying himself, the said lords and knights and their company to the Court, the Kings Highnesse then being at Greenwich. ${ }^{23}$

Here the reader is invited to connect the list of senior members of the embassy given with the prose account of the party's departure - to visualize, that is, the procession of figures, listed according to rank, as they take their leave.

Villamediana must have received help with identifying the masquers and those who processed into London; similarly, Treswell was assisted in identifying the eighty Spanish noblemen who participated in the Juego de Cañas on 31 May, for he states that 'The number of horsemen that shewed themselues in these sports were fourscore, whose names hereafter follow, according to a note thereof deliuered by one of good woorth and of especiall respect with the King. ${ }^{24}$ Divided into groups of five, two each of which formed a Quadrille, or squadron, the contest is described as follows:

After this, beganne their sports of Inego [sic] de Canas, wherein the King himself was an Actor. [...]

At their first appearance they came riding in by couples two after two, very swiftly, richly attired with their Targets on their shoulders, holding and shaking long staues such as the Moores or Arabians are described to vse. When they were all come, they diuided themselues to sides, euery side into foure squadrons, euery squadron being tenne in number; when they were ready holding their staues in their hands, the Kings side gaue

\footnotetext{
21 Ibidem $3-4$.

22 Ibidem 4.

23 Ibidem 5 .

24 Ibidem 47.
} 
the first charge; the other side vndertaking the same and charging on them likewise; thus they continued still chasing one another, squadron vpon squadron throwing their Canes one after other, by the space of a long houre or better: and so their sports ended. ${ }^{25}$

This description follows the double-page layout of the eight quadrilles [Fig. 9.1]. ${ }^{26}$ Here, as previously, the reader is invited to connect the prose description to the diagrammatic presentation of the formation, which in the mise-en-page represents the geometrical formation adopted by the horsemen. It is not made clear how the quadrilles engaged precisely, whether the first (led by Philip III) faced the fifth, the second the sixth, and so on, but if so, Treswell's

48

\begin{tabular}{|c|}
\hline 1. Quadrill. \\
\hline 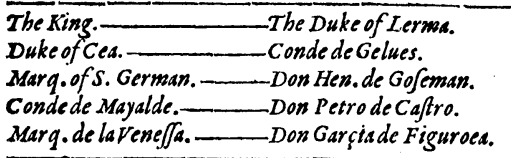 \\
\hline 2. Quadrill. \\
\hline 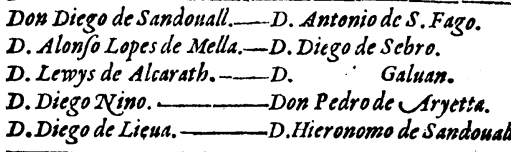 \\
\hline 3. Quadrill. \\
\hline 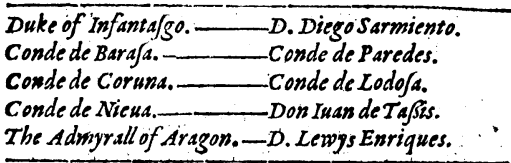 \\
\hline 4. Quadrill. \\
\hline 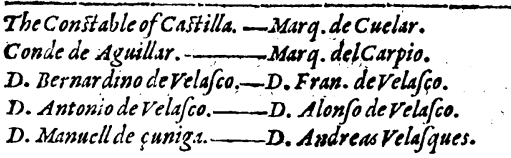 \\
\hline
\end{tabular}

\section{9}

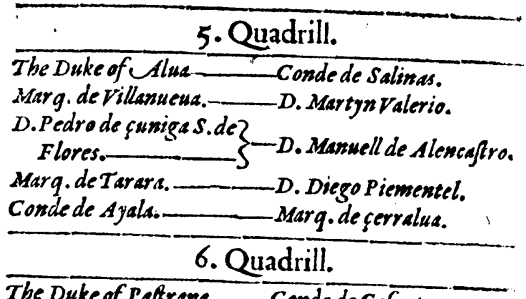

The Duke of Paftrana. Conde de Cofentagus. Concridador Mayor de?-D. Carlos de Borfa. Aarg. de Fuertes. - D. Lewys Tino. D. Pedro de Fonfeca.___D.Ferdimand: de la Cerda. D. Berward de Rozas._D. D. Dew Vicentela. 7. Quadrill.

Conde de Alualifa a. D. Bernard: de Toledo. D. Fernando de Toledo. D. Anto: de Toledo. D. Philippo de Valencia. - D. Fras. Congufta. D. Lewys de Gozman. D. Iwas de Gozman. Marq. de Alcanes. Marq. de Fales.

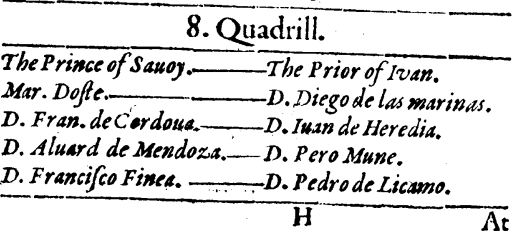

FIGURE 9.1 Robert Treswell, list of personages involved in the Juego de cañas, in A Relation of [...] the Journey of the right Honourable Charles Earle of Nottingham [...] Ambassadour to the King of Spaine (London, Melchisedech Bradwood: 1605) 48-49. RB69675, The Huntington Library, San Marino, California

25 Ibidem 47,5 o.

26 Ibidem $48-49$. 
layout (informed by a Spanish source) presented the reader with a visual image that was not simply a list of participants but which marked out both the physical space of the arena and the disposition of the caballeros. That is, the theatre of the Juego de Cañas is conjured on the page. If (clearly) the principal object of this activity was to convey Habsburg power - reminding those present that Spain was still a formidable power - this was available too (ironically, given the text's propagandistic purpose) to the reader of Treswell's Relation.

Treswell pays particular attention to the visual in another respect. Here is how the text describes the entry into Valladolid on 16 May. First, he lists the Spanish nobles who come out of the city to greet the Lord Admiral and his embassy, and then we read the following:

The order of our going into the towne was appointed as followeth: First rode two Trumpets, all the sumpter and carriages being about two hours before sent into the towne: after whom followed certain Gentlemen seruants to the Knights and Lords, as also the Leadger Ambassadors seuants in liueries very faire to the number of sixty. Then followed six Trumpeters of his Lordships in suits of Damaske holding their Trumpets in their hands, but not sounding. Then came diuers Gentlemen of good sort, with whom also followed his Lordships Gentlemen and principall Officers in their Liueries of blacke velvet to the number of thirty. Then followed the Esquires, Knights and Lords euery one according to their degree, being accompanied with seueral Spanish Knights and Lords; after whom came his Lordship $[\ldots] .{ }^{27}$

'Euery one according to their degree' is a code readily understood by the early modern reader, as is the significance placed on the colour of clothes, though there are other more illustrative examples. This procession, as a performance, signified both in Valladolid in May and in the text (and reader's imagination) some months later. It did so in part not only because diplomacy was performative, but because wider society was, too. As is well known, early modern England was a 'cloth society', as Ann Rosalind Jones and Peter Stallybrass remark, a society subject (until their repeal in 1603) to the longstanding 'sumptuary laws' that had been reinforced when Elizabeth I came to the throne and which governed who could wear what kind of fabric or colour of clothes, according to rank. ${ }^{28}$ These laws, for as long as they were enforced and enforceable,

27 Ibidem $3^{1-32 .}$

28 Jones A.R. - Stallybrass P., Renaissance Clothing and the Materials of Memory (Cambridge: 2000). 
codified a social hierarchy in visual terms, as Lisa Jardine has shown. ${ }^{29}$ When Treswell remarks on colours or materials of clothing, as he does in the above sequence, he does so because this information encodes social and hierarchical meaning. What it also does, simultaneously, is conjure up a theatre of socially stratified colour in the reader's imagination.

Thus, when Treswell placed dignitaries in their correct position according to rank (in Valladolid and in the text), he was creating and recording a visual display defined by colour, and hence by difference, and the early modern reader was guided by these descriptors. The descriptions of apparel we find here do not so much add colour as call up the semiotics of colour-coding; and this is underscored when the English aristocrats and their Spanish counterparts meet, the choreography - in which equals meet on equal terms - reinforcing the performative context through a stable, legible coding system that created in the reader a theatre of the mind, as it were. And although lost to us today, unless we study the sumptuary legislation that had been designed to regulate personal performance and representation until its repeal in 1603, the detailed information about fabrics, colours, and costume we find in texts such as these can offer us an insight into the performative nature of early modern diplomacy.

Although the conceit underpinning this chapter risks switching too radically between apparently distinctive genres of writing - the kind of risk James Thurber has great fun with when he has a modern reader mistakenly taking Macbeth for a murder-mystery whodunnit and concluding, with irresistible logic, that Macbeth could not have killed Duncan because, in whodunnits, the murderer is never revealed so early on - I want to take it further and propose that in fact diplomacy narratives offer much more information about actual performance than printed plays in early modern England. ${ }^{30}$ They are, in other words, better performance records of the events they purport to represent than printed plays.

If we consider Hamlet, for a moment, a play where Timothy Hampton fixes on the portrayal of diplomacy, we can readily see how and why it offers more for scholars interested in the literary intersections with diplomacy than for its depiction of actual practices, as Hampton's discussion demonstrates. The approach taken here both complements and departs from his thesis that 'the new political tool of diplomacy and the emerging culture of secular literature [in early modern Europe] shape each other in important ways', producing what

29 Jardine L., Still Harping on Daughters: Women and Drama in the Age of Shakespeare 2nd ed. (London: 1983) 141-168.

3o Thurber, J., "The Macbeth Murder Mystery", in The Secret Life of Walter Mitty and Other Pieces [1945] (London: 2000) 83-86. 
he terms a 'diplomatic poetics.' ${ }^{31}$ In his wide-ranging account that takes in the theories of Machiavelli, Gentili, and Guicciardini, among others, and explores the portrayal of diplomatic encounter in canonical literary texts such as Camões' Os Lusíads as well as Hamlet, Hampton argues that correspondences between diplomatic practice and literary genres point to a mutuallydetermining, symbiotic relationship: literary fictions depict diplomacy, which in turn draws on literary genres and conventions, not least in the scripting of communication between envoys and masters. In this respect Hampton echoes Hayden White, who contends that the writing of history employs literary genres to frame narrative (and, implicitly, conveys its moral). ${ }^{32}$ While Hampton notes that the 'theatricality' of the early modern court and the likening of diplomats to 'actors' was a cliché of the period, his concern is not with its enactment in physical time and space - that is, as theatre. ${ }^{33}$ 'Diplomatic missions', he writes, 'were generally understood, theoretically at least, as scripted and controlled units of movement'; $;$ but this insight is not developed in the direction of ceremonial. ${ }^{35}$ His persuasive reading of Hamlet focuses on how Claudius's instruction to his ambassadors is precisely calibrated so as to ensure that they conduct themselves to the letter of the commission; but it does not attempt to explore how a play might replicate diplomatic ceremonial in its very theatre, as for example we find in Janette Dillon's study of space in the early modern court. ${ }^{36}$ And yet if Hamlet in performance might offer a notable instance of the staging of diplomacy in a literary fiction, in print the case is less persuasive. If in seventeenth-century performance the play evoked and exploited contemporary awareness of diplomatic practices, the surviving textual witnesses offer little in the way of confirmation, if that was the case. The quarto and folio texts of Shakespeare's play $\left(\mathrm{Q}_{1}, 1603\right.$; $\left.\mathrm{Q}_{2}, 1605 ; \mathrm{F}, 1623\right)$ - like any other surviving printed (or manuscript) play of the period - privileges the Haupttext, or dialogue, over the Nebentext, or stage movement information, something that historically has not worried too many literary critics but poses problems for

31 Hampton T., Fictions of Embassy: Literature and Diplomacy in Early Modern Europe (Ithaca and London: 2009) 2.

32 See White H., Metahistory: The Historical Imagination in Nineteenth-Century Europe (Baltimore: 1973) and The Content of the Form: Narrative Discourse and Historical Representation (Baltimore: 1987).

33 Hampton, Fictions of Embassy 142-143 and passim.

34 Ibidem 154.

35 Indeed, Roosen's essay is not included in Hampton's extensive bibliography.

36 See Dillon, The Language of Space; Dillon does include Roosen's essay in her bibliography but does not discuss it. See also Dillon J., Performance and Spectacle in Hall's Chronicle (London: 2002). 
those scholars interested in performance. Early modern readers of this play, like modern directors, receive no guidance as to which entry or exit points are used on the stage, and the order in which characters in group entrances or exits move is not indicated; nor, crucially, is the relative placement on the stage - the blocking of characters - in any way clarified. And while sometimes the dialogue includes what scholars refer to as 'implicit stage directions', which might indicate that a character has kneeled or removed headwear, for example - and indeed in a play about a royal court the actors must have observed at least some of the protocol through which early modern subjects understood the social make-up and hierarchy of their world - nevertheless the textual witnesses are notoriously silent on choreography.

These texts that lay claim to being 'documents of performance' - or, rather, have such claims thrust upon them by scholars - offer very little evidence of how performances of stage plays were choreographed. Accounts of diplomatic practice, on the other hand, are textual representations of a certain type of performance first and foremost. Performance, central as it is to early modern diplomatic practice, is correspondingly prominent in these texts. Tresswell's account of the visit of the English embassy to Valladolid is more than an account - it is a record of the choreography of encounter between Spanish and English figures in a variety of formal occasions and events, public and private, from the embassy's arrival in A Coruña to its departure from Santander: a choreography in which Tresswell, as Somerset Herald, played a major role. As such, he understood not only the importance of providing an accurate - plain account, but that readers would decode the performance rendered by the text, that their world - however remote from high offices of state - was also codified and organized according to the rules of ceremonial. And as choreographer he was in a position to oversee the entire 'production' - from the planning of each official event to its recording and eventual rendering into print. ${ }^{37}$

Take for example this description of the ceremonial ratification of the peace treaty, which, if read as a kind of extended stage direction, is much more informative than the kind of Nebentext we find in printed drama: ${ }^{38}$

This, admittedly, is mostly surmise, since no evidence has survived to indicate that Robert Treswell oversaw the printing of the text he authored, either in London or Edinburgh; and no manuscript exists. But given the political importance of the English embassy - above all domestically, as well as internationally - it would seem reasonable to conclude that Treswell was commissioned (and made aware of the commission) to provide an authoritative account of the embassy's reception prior to its sailing from England. At any rate the anonymous author of The Royal Entertainement evidently saw a way to capitalize on an opportunity that may well have arisen from knowledge of Treswell's commission.

38 Dillon, The Language of Space 1-4, discusses an elaborate stage direction in Shakespeare and Fletcher's Henry VIII, but as she points out, here the play was indebted to the chronicle sources. 
His Lordship being thus receaued, was conueied vp through a long Gallery into a Presence, and so into another inner roome: the Gentlemen, Knights and Lords euer going before in very good order. In which roome his Maiestie staied for the coming of his Lordship, receauing him with affable and kind congratulation, and tooke him along with him by his side. The Kings Sergeaunts at Mace going first, after following all the Graundes and Lords of Spaine one among another: then the foure Kings of Armes in their coats of Armes: then the Duke of Lerma bearing the Sword naked, wherein one thing is especially to be noted, that the Duke bare not the Sword vpright, as is the custome of England, but bare it lying vpon his right shoulder: so the King and his Lords went together into a very faire banquetting house verie lately built, the Ambassadour Leadger, the Lords and diuers others following. ${ }^{39}$

Here we have what is unquestionably an eyewitness description of diplomatic ceremonial, where attention is paid especially to the treatment of the Lord Admiral by Philip III, who 'tooke him along with him by his side'. The banqueting house to which the party is conveyed had been specially constructed for the occasion of the peace. Treswell takes the reader into this elite, restricted space, through 'a long Gallery into a Presence, and so into another inner roome', where Philip awaits the Lord Admiral, and then on 'into a very faire banqueting house verie lately built'. Here once more Treswell is concerned with movement through space and the relative proximity of the dignitaries; as elsewhere, Nottingham's favourable treatment (for which the Spanish texts do not offer corroboration) is prominent.

At this point Treswell's account continues; note the attention given to proxemics and the actions of the dignitaries:

The King sitting in his Estate, his Lordship and the Ambassadour Leadger were placed vpon his left hand: the Grandees and other the Noblemen of Spaine being seated on the other hand, two degrees lower. Before the King was brought a little Table, whereon lay the Bible and a Crucifix vpon it. The Archbishop of Toledo read the oath with a reasonable loud voice: at one part of the oath his Lordship held the Kings hands between his: to which oath the King sware kneeling and laying his hand vpon the Booke, and afterwards subscribed to the Articles and Agreements drawen and concluded by both Kings. ${ }^{40}$ 
Treswell is alert to important details ('two degrees lower'): he understood the significance of this, and clearly he expected his domestic readership to recognize the compliment being paid to James' representatives - and thus to the King of England himself.

This kind of expectation was keyed, as we have seen, to a specific kind of visual semiotics in early modern culture, whether relating to attire, which signified rank and hierarchy, or movement through space, which was restricted and similarly codified. The theatricality of diplomacy was reproducible and reproduced textually. Indeed, in print diplomatic activity was conveyed precisely through its affinity with stage performance; but whereas plays privileged speech (the Haupttext), the absence of dialogue in these diplomacy narratives partly displaced by the narrative voice of the author-witness - opened up a space for the privileging of the Nebentext. If the conceit that diplomacy was theatrical or performative is accepted, we may thus regard narratives such as Treswell's as composed principally of a series of stage directions, of choreographed movement, otherwise known as ceremonial. To do so is not only to reread these texts through a different kind of cultural frame of reference but also to recognize that diplomacy and theatre drew on a shared language that was principally grounded in the visual, particularly with respect to the choreographing of important state occasions. Behind the 'plainnesse' of Treswell's style - or, rather, imbued within it - lay the essence of diplomatic ceremonial, translated into prose.

To describe early modern diplomacy as 'theatrical' - or, more properly, its representation, from private (or quasi-private - that is to say, elite) encounter to full-scale, public ceremonial - is not only to call up through analogy a social and cultural practice that was also (in parallel in England and Spain) establishing itself over the course of the sixteenth century as a professional activity, but also to risk treating the evidentiary basis for such a claim as primarily a scholarly source. ${ }^{41}$ In mining texts such as Treswell's for what they can tell us about past historical events we lose sight of how they operated in their own time, for their readers. Precisely how early moderns read these accounts is largely beyond retrieval of course, and we must allow for resistant readings: indeed, given the unpopularity of the peace policy it is surely beyond doubt that for some their textual engagement was overdetermined by fears for England's future. But when we approach these texts on their own terms, consider their design, and think in terms of the 'ideal reader' - then it is possible to interrogate

41 For a comparative study of the emergence of the English and Spanish traditions, see Cohen W., Dream of a Nation: Public Theater in Renaissance England and Spain (Ithaca London: 1985). 
the concept of 'theatricality' at the level of the text itself. In other words, this chapter has urged that we attend to these texts not simply or solely as sources of evidence for the performance of diplomatic ceremonial in early modern Europe but as evidence of how diplomacy was framed and shaped for a nonelite (if not popular) audience through the medium of print.

The conceit I have explored here might be considered less outlandish than it appears once we recognize that the implicit claims of any printed play - that the text represents theatrical performance - is inherently problematic; and yet, we habitually use the printed text ('drama') as the basis for putative 'reconstructions' of past and future performance ('theatre'). But if the printed play, both in content and form, nonetheless offers itself as just such a representation, notwithstanding the insurmountable obstacles that arise in representing one medium through another, perhaps it is possible to see not only the problems in approaching the genre of diplomacy narratives in a similar fashion but also the strategies deployed by the authors of these texts to capture, however imperfectly, the theatricality of diplomatic encounter. Indeed, if our understanding of theatricality in the playhouses of early modern England (or Spain) is entirely text-derivative - and it is - then we ought to acknowledge not only (as we do) that print supplies for us now the basis for our scholarly activities in conjuring up performance but also that these texts are, for all their 'deficiencies' as imperfect records of performance, our only starting point. That is, they were also, for early modern readers, their starting point, too, for a vicarious experience of performance through the act of reading.

Given the importance of ceremonial for the practice of diplomacy and, as I have argued here, its corresponding significance in the textual representation of diplomacy, and bearing in mind the growth in the printing of plays from the 159os onwards, which testifies to the demand for, supply of, and familiarity with such texts, it is not unreasonable to suppose that readers of Treswell's account were equipped to interpret the text's rendering of performance..$^{42}$ Not all playgoers were playreaders, but it is worth remembering that the pageantry of ceremonial that early moderns witnessed in the streets of London was staged in the playhouses, too, and the symbolism of diplomatic ceremonial - its visual, proxemic ordering and presentation of the social order as choreographed performance - was not so much exotic and different so much as a perhaps more refined version of familiar behaviour; it is not so much that high-status figures like nobles and ambassadors were familiar because they travelled publicly

42 On the printing of plays in early modern London, see Blayney P., "The Publication of Playbooks", in Kastan D.S. - Cox J.D. (eds.), A New History of Early English Drama (New York: 1997) 383-422. 
through the streets of London, more that early modern society understood the kinds of social codes that were as central to the 'performance' of diplomacy as they were to any other aspect of society - itself understood in anthropological terms as ritual. As a herald Treswell understood this doubly. It was his duty to order things correctly when he choreographed events; and he sought to convey the precision of this orchestration in the text that he produced for publication. He did so by providing what in theatrical terms we might regard as an extended 'dumb show', where the visual is all; and this works because the governing proxemics and protocols are not only familiar to him but, through his text, recognized by the reader also. Indeed, what is striking about these texts, their subject matter, construction, and reception - and this is so obvious as to pass without comment from scholars - is that the high-status activity that was early modern diplomacy could be conveyed to and understood by a non-elite audience precisely because its textual form relayed information that could be readily understood within the cognitive framework of more general knowledge of a hierarchical society. Moreover, as I have argued above, if we consider the set-piece descriptions of diplomatic activity as examples of an extended Nebentext, a kind of dumbshow with which playreaders were familiar, then the 'theatricality' of diplomatic ceremonial may be understood as principally and most usefully as a textual attribute, for what this genre calls up is a text-reader relationship analogous to the culture of reading printed drama. Treswell's text operated on these terms.

\section{Bibliography}

\section{Primary Sources}

The Royal Entertainment of the Right Honourable the Earle of Nottingham, sent Ambassador from his Maiestie to the King of Spaine (London, Valentine Sims: 1605).

Treswell Robert, A Relation of Svch Things As were obserued to happen in the Journey of the right Honourable Charles Earle of Nottingham, L. High Admirall of England, his hignesse Ambassadour to the King of Spaine (London, Melchisedech Bradwood: 1605).

\section{Secondary Sources}

Blayney P., "The Publication of Playbooks", in Kastan D.S. - Cox J.D. (eds.), A New History of Early English Drama (New York: 1997) 383-422.

Bruster D., "Shakespeare's Literary Stage Directions", in Dustagheer S. - Woods G. (eds.), Stage Directions and Shakespearean Theatre (London: 2018) 115-137. 
Cano-Echevarría B. - Hutchings M., "The Spanish Ambassador and Samuel Daniel's Vision of the Twelve Goddesses: A New Document [with Text]", English Literary History 42, 3 (2012).

Cohen W., Dream of a Nation:Public Theater in Renaissance England and Spain (IthacaLondon: 1985).

Dillon J., "The Trials of Queen Katherine in Henry VIII", Shakespeare Survey 63 (2010) 149-161.

Dillon J., Performance and Spectacle in Hall's Chronicle (London: 2002).

Dillon J., The Language of Space in Court Performance, 1400-1625 (Cambridge: 2010).

Dustagheer S. - Woods G. (eds.), Stage Directions and Shakespearean Theatre (London: 2018).

Fuller M.C., "His dark materials': The Problem of Dullness in Hakluyt's Collections", in Carey D. - Jowitt C. (eds.), Richard Hakluyt and Travel Writing in Early Modern Europe (London - New York: 2016) 231-242.

Hampton T., Fictions of Embassy: Literature and Diplomacy in Early Modern Europe (Ithaca and London: 2009).

Hutchings M. - Cano Echevarría B., “The Spanish Ambassador's Account of James I's Entry into London, 1604 [with Text]", The Seventeenth Century 33, 1 (2018) 255-277.

Ingarden R. Das Literarische Kunstwerk (Halle: 1931) 231-242.

Jardine L., Still Harping on Daughters: Women and Drama in the Age of Shakespeare and ed. (London: 1983).

Jones A.R. - Stallybrass P., Renaissance Clothing and the Materials of Memory (Cambridge: 2000).

Kidnie M.J., "Text, Performance, and the Editors: Staging Shakespeare's Drama", Shakespeare Quarterly 51, 4 (2000) 456-473.

Lopez J., "Dumb Show”, in Turner H.S. (ed.), Early Modern Theatricality (Oxford: 2013) 291-305.

Roosen W., "Early Modern Diplomatic Ceremonial: A Systems Approach", Journal of Modern History 52, 3 (1980).

Smith E., "Reading Shakespeare's Stage Directions", in Dustagheer S. - Woods G. (eds.), Stage Directions and Shakespearean Theatre (London: 2018) 93-114.

Smith H. - Wilson L. (eds.), Renaissance Paratexts (Cambridge: 2011).

White H., Metahistory: The Historical Imagination in Nineteenth-Century Europe (Baltimore: 1973).

White H., The Content of the Form: Narrative Discourse and Historical Representation (Baltimore: 1987).

Wigham F. - Rebhorn W.A. (eds.), The Art of English Poesy by George Puttenham: A Critical Edition (Ithaca - London: 2007). 